Journal of Applied Pharmaceutical Science Vol. 5 (06), pp. 138-147, June, 2015

Available online at http://www.japsonline.com

DOI: $10.7324 /$ JAPS.2015.50623

ISSN 2231-3354 (cc) BY-NC-SA

\title{
Antioxidant, antimicrobial activities of flavonoids glycoside from Leucaena leucocephala leaves
}

\author{
Reda S. Mohammed ${ }^{1 *}$, Sahar S. El Souda ${ }^{2}$, Hanan A.A. Taie ${ }^{3}$, Maysa E.Moharam ${ }^{4}$, Kamel H. Shaker ${ }^{2}$ \\ ${ }^{1}$ Pharmacognosy Department, ${ }^{2}$ Chemistry of Natural Compounds Deptartment, ${ }^{3}$ Deptartment of Plant Biochemistry, ${ }^{4}$ Microbial chemistry department, \\ National Research Centre, 33 Bohouth Street, Dokki, , Cairo, Egypt.
}

\author{
ARTICLE INFO \\ Article history: \\ Received on: 24/03/2015 \\ Revised on: 08/04/2015 \\ Accepted on: 03/05/2015 \\ Available online: 27/06/2015 \\ Key words: \\ Leucaeana leucocephala, \\ acylated flavonol glycoside, \\ antioxidant activity, DPPH, \\ ABTS, FRAP, Metal \\ chelating, Reducing power, \\ antimicrobial.
}

\begin{abstract}
The study aimed to identify the chemical constituents of Leucaeana leucocephala leaves and evaluate the antioxidant and antimicrobial activities of the extract and compounds. An acylated flavanol glycoside, quercetin 3 -O-(2"-trans- $p$-coumaryl)- $\alpha$-rhamnopyranosyl-(1"' $\rightarrow 6 ")-\beta$-glucopyranoside (1) in addition to quercetin-3-O- $\alpha$ rhamnopyranosyl-(1"'-2")- $\beta$-glucopyranoside (2), quercetin-7-O- $\alpha$-rhamnopyranosyl-( 1 "' $\rightarrow 2$ ")- $\beta$-glucopyrano side(3), quercetin-3-O- $\alpha$ - rhamnopyranoside(4), quercetin-3-O- $\beta$-glucopyranoside (5), isovitexin( 6), vitexin (7) and quercetin (8) were isolated for the first time from the Leucaeana leucocephala. The antioxidant activity of the extract and the isolated compounds $1,3 \& 4$ were evaluated by Reducing Power, FRAP, DPPH, Metal chelating and ABTS assays. Compound (3) recorded the highest antioxidant activity in comparison with the extract and other compounds. The extract and compound 1,2, 3 and 5 were studied for their antimicrobial activity. Both the extract and compound 1 have significant activity against gm-ve bacteria, moderate to gm +ve and Candida and inactive towards fungi. The structures of compounds were elucidated on the basis of spectral analysis. L. leucocephala possess good antioxidant, antibacterial properties and could serve as free radical inhibitors or scavengers, acting possibly as primary antioxidants and have to be investigated for antiinflammatory and anticancer activities.
\end{abstract}

\section{INTRODUCTION}

Leucaena leucocephala (Fabaceae) is a small plant, fast growing, multipurpose, nitrogen fixing tree legume widely distributed throughout the tropics and subtropics. (Yeung et al., 2004, Ramana et al., 2000). The plant used as foliage, as a source of vitamin $\mathrm{K}, \beta$-carotene, fuel wood, green manure, or as drought resistance (Lalitha et al., 1993) it also has various medicinal properties (Salem et al., 2011). Different constituents were detected in GC-MS analysis of dichloromethane extract of the leaves (Chen and Wang, 2010). The leaves (Nair and subramanian, 1962, Ranganthan and Nagarajan, 1980) and the flowers (Nokata et al., 1977, Lowry et al., 1984) of $L$. leucocephala were reported for their flavonoids contents while the roots were studied for tannins which exhibited nitrification inhibition effect (Erickson et al., 2000). Aerial parts (Haggag et al., 2011) and ethanol extract of the pods (Helana and Josline

\footnotetext{
* Corresponding Author

Email: reda_sayed2008@yahoo.com

Mob: +202-01227636237
}

2007) were studied for their flavonoids, Cytotoxic and DPPH antioxidant activity. Sulphated Polysaccharide from seeds of Leucaena leucocephala was reported to have cancer chemopreventive and anti-proliferation activity against human hepatocarcinoma (Gamal-Eldeen, 2007). The phyto-chemical investigation of L. leucocephala revealed the presence of terpenes, flavonoids, coumarins and sterols (Hassan et al., 2014). In recent years, there has been a considerable interest in finding natural antioxidants from plant materials. The antioxidant phytochemicals from plants, particularly flavonoids and other polyphenols, have been reported to inhibit the propagation of free radical reactions, protect the human body from disease (Kinsella, et al., 1993; Terao and Piskula,1997), and retard lipid oxidative rancidity (Duthie, 1993). Moreover, the use of synthetic antioxidants has been questioned because of their toxicity (Valentao et al., 2002). Therefore, there have been numerous researches on these bioresources to seek for natural and possibly economic and effective antioxidant to replace the synthetic ones. The work aimed to identify the phenolic compounds and to evaluate the antioxidant activity of Leucaena leucocephala leaves and isolated flavonoids. 


\section{MATERIALS AND METHODS}

\section{General}

The structure of the compounds was identified by spectroscopic methods including: ultraviolet and visible absorption spectrometer (UV-VIS, Labomed Inc.) for measuring UV spectral data of the isolated compounds, in the range of $200-500 \mathrm{~nm}$ in methanol and with different diagnostic shift reagents. Nuclear magnetic resonance spectrophotometer (NMR, Bruker, $500 \mathrm{MHz}$ for determination of ${ }^{1} \mathrm{H}-\mathrm{NMR}$ and $125 \mathrm{MHz}$ for determination of ${ }^{13} \mathrm{C}-\mathrm{NMR}$ ), ESI-MS [electrospray ionisation mass spectrometer (ion trap), Thermo Finnigan] for determination of molecular weight of the compounds. Column chromatography was carried out on polyamide 6S (Riedel-De-Haen AG, Seelze Haen AG, D30926 Seelze Hanver, Germany) and Sephadex LH-20 (Pharmazia). Paper chromatography (PC, descending) Whatman No. 1 and 3mm papers, using solvent systems 15\% HOAc (H2OHOAc, 85:15), BAW (n-BuOH-HOAc-H2O, 4:1:5, upper layer). The aglycon and sugar moieties were identified by complete acid hydrolysis for $-O$ - glycosides followed by co- chromatography with authentic samples (Sigma) (Mabry et al. 1970). Solvents used for plant extraction were purchased from SDFCL (Industrial Estate, 248 Worli Road, Mumbai, 30, India). Material used for antioxidant study: 1, 1-Diphenyl-2-picrylhydrazyl (DPPH), potassium ferricyanide, Trolox, ferrozine, 2,2'-azinobis-3ethylbenzothiazoline-6-sulfonicacid(ABTS), 3- (2-pyridyl)-5,6 diphenyl-1,2,4-triazine-4',4"-disulfonic acid, potassium ferricyanide, butylated hydroxytoluene (BHT), $\mathrm{FeCl}_{2}$ and $\mathrm{FeCl}_{3}$. All chemical were purchased from Sigma Chemical Co. (St.Louis, MO, USA). All solvents were of analytical grade.

Materials for antimicrobial study: Bacteria, fungi and yeast strains were available in Microbial Chemistry Department, NRC, Egypt. All chemicals used in the preparation of media were of analytical grade. Routine sterilization was carried out by autoclaving for $20 \mathrm{~min}$ at $15 \mathrm{psi}\left(121^{\circ} \mathrm{C}\right)$. Tested microorganisms (MO) two gram +ve bacterial strains: Bacillus cereus and Staphylococcus aureus ATCC 6538 and three gram -ve bacterial strains:, Escherichia coli NRRN 3008 and Pseudomonas aeruginosa ATCC 10145 and Salmonella typhimurium ATCC 25566. Yeast, Candida albicans EMCC 105. Three Fungi: and Aspergillus niger NRRL 595, Mucor miehei NRRL 2034 and Rhizopus oligosporus NRRL 2710.

The Media used for culturing the MO, nutrient agar media (Marshall. 1993) for bacteria, Potato- dextrose agar (PDA)(Subba Rao. 1977) culturing the fungi in solid media, Yeast extract peptone dextrose (YEPD) (Dillon et al. 1985) for yeast. Standard drugs: Ampicillin (Wyeth) was used as reference antibacterial agent, while Clotrimazole (Bayer) was used as a reference antifungal drug.

\section{Plant material}

Fresh leaves of Leucaena leucocephala (Lam.) were obtained from Agriculture research center, Giza Egypt in Mars 2009; the plant was identified by Mrs Terase Labib, Taxonomist of
Orman Garden. A voucher specimen $127 \mathrm{M}$ has been deposited in the Herbarium of National Research Centre.

\section{Extraction and Isolation}

Dried powdered leaves of Leucaena leucocephala $(1 \mathrm{~kg})$ were defatted with chloroform, and then extracted with $70 \%$ aqueous ethanol, at room temperature, to give DAEE (75g). Part of DAEE extract was dried under reduced pressure and subjected to in-vitro antioxidant and antimicrobial assay. DAEE was dissolved in water and subjected to reversed phase chromatography on polyamide $6 \mathrm{~S}$ column starting elution with water till $100 \%$ methanol. Fractions of $500 \mathrm{ml}$ each were collected inspected on Whatman PC 1MM, four main fractions (A-D) were obtained by combining similar fractions according to their PC (1 MM) properties using butanol: acetic acid: water, 4:1:5 (BAW) and 15\% acetic acid as solvent systems. Fraction A eluted with 20\% methanol/water was subjected to PC using BAW, led to the isolation of compounds $(2,3)$ each compound was further purified on a Sephadex LH-20 column using $\mathrm{H}_{2} \mathrm{O} / \mathrm{MeOH}$ (7:3) as eluent. Fraction B eluted with $30 \%$ methanol / water was subjected to PC fractionation using $15 \%$ acetic acid /water $(\mathrm{ACOH})$, led to the isolation of compound (1), which was purified on a Sephadex LH20 column using $\mathrm{H}_{2} \mathrm{O} / \mathrm{MeOH}(7: 3)$ as eluent. Fraction $\mathrm{C}$ eluted with $40 \%$ was subjected to $\mathrm{PC}$ fractionation using $\mathrm{ACOH}$ system to give three major bands $(\mathrm{C} 1, \mathrm{C} 2$ and $\mathrm{C} 3) . \mathrm{C} 1 \& \mathrm{C} 2$ were further chromatoghraphed on Sephadex LH-20 column using methanol/ water $(20 \%)$ led to the isolation of compounds $(4,5)$. While $(\mathrm{C} 3)$ was applied on silica gel column and eluted with chloroform / water 7:3 led to the isolation of compounds (6) and (7). Fraction D eluted with $60 \%$ methanol/water was subjected to Sephadex using $\mathrm{MeOH}-\mathrm{H}_{2} \mathrm{O}(1: 1)$ to yield compounds 8 . Final purification of all compounds was achieved by Sephadex LH20 column using $\mathrm{MeOH}$ as eluent (Mabry et al., 1970).

Compound(1): Quercetin-3-O-(2"-trans-p-coumaroyl)- $\alpha$ rhamnopyranosyl-(1"' $\rightarrow 6$ ")- $\beta$-glucopyranoside

UV-vis $(\mathrm{MeOH}) \lambda \max (\mathrm{nm}): \mathrm{MeOH}: 265,350$; NaOMe: 270, 405; $\mathrm{AlCl}_{3}: 273,310,370,390,405,435 ; \mathrm{AlCl}_{3} / \mathrm{HCl}: 273,310$, 330,360, 395; NaOAc: 270, 305 360; $\mathrm{NaOAc} / \mathrm{H}_{3} \mathrm{BO}_{3}$ : 265,320, 380. Negative ESI-MS: m/z755.73 (calculated for molecular formula $\mathrm{C}_{36} \mathrm{H}_{36} \mathrm{O}_{18}$.

${ }^{1} \mathrm{H}-\mathrm{NMR}$ (500 MHz, DMSO-d6, ppm ) $\delta: 7.628(1 \mathrm{H}, \mathrm{d}, J=2.3 \mathrm{~Hz}$, H-2 $\left.{ }^{\prime}\right), \delta 7.542\left(1 \mathrm{H}, \mathrm{dd}, J=2.3,8.4 \mathrm{~Hz}, \mathrm{H}-6^{\circ}\right), 6.860(1 \mathrm{H}, \mathrm{d}, J=8.4$ Hz, H-5'), $6.224(1 \mathrm{H}, \mathrm{d}, J=2.0 \mathrm{~Hz}, \mathrm{H}-8), 6.035(1 \mathrm{H}, \mathrm{d}, J=2.0$ Hz, H-6), 5.687 (1H, d, $\left.J=7.4 \mathrm{~Hz}, \mathrm{H}-1^{\prime \prime}\right), 5.219(1 \mathrm{H}, \mathrm{d}, J=1.5 \mathrm{~Hz}$, H-1"') 3.5-4.1 (m H-2", H-3", H-4", H-5"), 4.30 (1H, d, J = 11.5 Hz H -6"a) and 4.20 (1H, dd, $J=11.6,6.7$ Hz H 6"-b). 7.321 (1H, d, $\left.J=15.9 \mathrm{~Hz}, \mathrm{H}-7^{\prime \prime}\right), 7.202$ (2H, brd, $\left.J=8.5 \mathrm{~Hz}, \mathrm{H}-2^{\prime \prime}, 6^{\prime \prime \prime}\right)$, $6.751\left(2 \mathrm{H}\right.$, brd, $\left.J=8.5 \mathrm{~Hz}, \mathrm{H}-3^{\prime \prime}, 5^{\prime \prime \prime}\right), 6.004(1 \mathrm{H}, \mathrm{dd}, J=15.9,1.2$ $\mathrm{Hz}, \mathrm{H}-8 " ')$.

${ }^{13}$ C-NMR (125 MHz, DMSO-d6, ppm ) $\delta: 178.0(\mathrm{C}-4), 164.3(\mathrm{C}-7)$, 161.6(C-5), 157.4(C-2), 157.0(C-9), 149.4(C-4'), 146.8(C-3'), 134.5(C-3), 122.4(C-6'), 120.68 (C-1'), 114.5(C-5'), 112.8(C-2'), 103.6(C-10), 99.88(C-6), 94.60(C-8), 165.68(C-9'"'), 158.41(C- 
4'"'), 145.1(C-7'"'), 129.8(C- 2"'", 6'"'), 125.5(C-1"'"), 115.3(C-3"'", $5^{\prime \prime \prime \prime), ~ 113.1(C-8 ' " '), ~ 102.3(C-1 "), ~ 76.5(C-3 "), ~ 74.4(C-5 "), ~ 77.50(C-~}$ 2"), 70.3(C-4"), 64.36(C-6"), 100.68 (C-1"'), 72.44 (C-2"'), $72.36(\mathrm{C}-3$ "'), 69.93 (C-4"'), 71.06 (C-5"'), 17.45(C-6"').

Compounds $2-8$ were isolated for the first time from the investigated plant, their structure elucidation was carried out through Rf-values, colour reactions, chemical investigations (complete and mild acid hydrolysis) and spectral investigations (UV, NMR and MS) (Mabry et al. 1970; Markham 1982; Agrawal 1989).

\section{Investigation of antioxidant activity Antioxidant Activity (DPPH Assay)}

The free radical scavenging activity using the 1,1diphenyl-2-picryl-hydrazil (DPPH) reagent was determined according to Brand-Williams et al., (1995). The extract and the isolated compounds of L. leucocephala were dissolved in $85 \%$ methanol: water. To $0.5 \mathrm{ml}$ of the extract sample $1.0 \mathrm{ml}$ of freshly prepared methanolic DPPH solution $\left(20 \mu \mathrm{g} / \mathrm{ml}^{-1}\right)$ was added and stirred. The discoloration processes was recorded after $5 \mathrm{~min}$ of reaction at $517 \mathrm{~nm}$ and compared with a blank control.

Antioxidant activity $(\%)=$

[(control absorbance - sample absorbance) / control absorbance] $\times$ $100 \%$

\section{Reducing power Assay}

The reducing power of the extract and the isolated compounds of L. leucocephala were determined according to the method of Oyaizu, (1986). $0.5 \mathrm{ml}$ of crude plant extract and isolated compounds were added to Phosphate buffer $(2.5 \mathrm{ml}, 0.2$ $\mathrm{M}, \mathrm{pH} 6.6)$ and $1 \%$ potassium ferricyanide $(2.5 \mathrm{ml})$. The mixture was incubated at $50{ }^{\circ} \mathrm{C}$ for $20 \mathrm{~min}$. Aliquots of trichloroacetic acid (2.5 $\mathrm{ml}, 10 \%)$ were added to the mixture, which was then centrifuged at $1000 \mathrm{rpm}$ for $10 \mathrm{~min}$. The upper layer of solution $(2.5 \mathrm{ml})$ was mixed with distilled water $(2.5 \mathrm{ml})$ and a freshly prepared $\mathrm{FeCl}_{3}$ solution $(0.5 \mathrm{ml}, 0.1 \%)$. The absorbance was measured at $700 \mathrm{~nm}$. Increased absorbance of their reaction mixture indicated increased reducing power.

\section{Metal Chelating activity assay}

The chelation of ferrous ions by extract and isolated compounds of L. leucocephala was estimated according to the method of Dinis et al. (1994) $0.5 \mathrm{~mL}$ of crude extract and isolated compounds were added to a solution of $50 \mu \mathrm{L} \mathrm{FeCl}_{2}(2 \mathrm{mM})$. The reaction was initiated by the addition of $200 \mu \mathrm{L}$ ferrozine $(5 \mathrm{mM})$, and then the mixture was shaken vigorously and left to stand at room temperature for $10 \mathrm{~min}$. After equilibrium had been reached, absorbance of the solution was measured at $562 \mathrm{~nm}$. The percentage of inhibition of ferrozine-Fe ${ }^{2+}$ complex of each sample was calculated according to the following formula:

$$
\% \text { inhibition }=[(\text { Abs control }- \text { Abs sample }) / \text { Abs control }] \times 100
$$

Where, Abs control is the absorbance reading of control and Abs sample is the absorbance reading of sample.

\section{Ferric reducing antioxidant power assay (FRAP)}

The FRAP assay was done according to Benzie and Strain (1999) with some modifications. The stock solutions included $300 \mathrm{mM}$ acetate buffer, $\mathrm{pH}$ 3.6, $10 \mathrm{mM}$ TPTZ (2, 4, 6tripyridyl-s-triazine) solution in $40 \mathrm{mM} \mathrm{HCl}$, and $20 \mathrm{mM}$ $\mathrm{FeCl}_{3} \cdot 6 \mathrm{H}_{2} \mathrm{O}$ solution. The fresh working solution was prepared by mixing $25 \mathrm{ml}$ acetate buffer, $2.5 \mathrm{ml}$ TPTZ solution, and $2.5 \mathrm{ml}$ $\mathrm{FeCl}_{3} \cdot 6 \mathrm{H}_{2} \mathrm{O}$ solution and then warmed at $37{ }^{\circ} \mathrm{C}$ before using. The extract and isolated compounds of Leucenia leucocephala $(50 \mu \mathrm{l})$ were allowed to react with $2850 \mu$ of the FRAP solution for 30 min in the dark condition. Readings of the colored product [ferrous tripyridyltriazine complex] were then taken at $593 \mathrm{~nm}$. Results are expressed in $\mu$ mol Trolox / $g$ dry matter. Additional dilution was needed if the FRAP value measured was over the linear range of the standard curve.

\section{ABTS radical scavenging assay}

ABTS assay was carried out using the method of Re et al., (1999). The stock solutions included $7 \mathrm{~m} \mathrm{M}$ ABTS solution and $2.4 \mathrm{mM}$ potassium persulfate solution. The working solution was then prepared by mixing the two stock solutions in equal quantities and allowing them to react for $12 \mathrm{hr}$ at room temperature in the dark. The solution was then diluted by mixing $1 \mathrm{ml}$ ABTS. $^{+}$Solution with $60 \mathrm{ml}$ methanol to obtain an absorbance of $0.706 \pm 0.001$ units at $734 \mathrm{~nm}$ using the spectrophotometer. ABTS. ${ }^{+}$Solution was freshly prepared for each assay. Plant extract and isolated compounds $(0.5 \mathrm{ml})$ were allowed to react with $3 \mathrm{ml}$ of the ABTS.+ Solution and the absorbance were taken at $734 \mathrm{~nm}$ after $7 \mathrm{~min}$ using the spectrophotometer. The ABTS. $^{+}$scavenging capacity of the extract and isolated compounds percentage inhibition calculated as ABTS radical scavenging activity using the following equation.

$(\%)=[($ Abs.control - Abs.sample $)] /($ Abs.control $)] \times 100$

Where Abs. controls the absorbance of ABTS radical cation methanol; Abs.sample is the absorbance of ABTS radical cation sample extract. Each of the above assays was carried out in triplicate.

\section{Antimicrobial activity}

The extract and the isolated compounds 1, 3 and 4 of L. leucocephala were screened for their anti-microbial effect against gram +ve bacteria, gram -ve bacteria, fungi and yeast, using the diffusion assay method (Hammond and Lambert 1978). A sterilized filter paper disc saturated with measured quantity $(20 \mu \mathrm{l})$ of the sample $(1 \mathrm{mg} / \mathrm{ml})$ was placed on a plate of $10 \mathrm{~cm}$ diameter containing a solid bacterial, fungal or yeast medium which has been seeded with the spore suspension of the test organism. After incubation at $37^{\circ} \mathrm{C}$ for $24 \mathrm{~h}$. for bacteria (in case of fungi, at $25{ }^{\circ} \mathrm{C}$ for $72 \mathrm{~h}$., while yeast at $28^{\circ} \mathrm{C}$ for $24 \mathrm{~h}$.), the diameter of the inhibition zone surrounding the sample is taken as a measure of the inhibitory power of the sample against the particular test organism. Ampicillin $(20 \mu \mathrm{l})$ (Wyeth) and Clotrimazole $(20 \mu \mathrm{l})$ (Bayer) were used as reference drugs for broad-spectrum antibacterial and antifungal agents, respectively. 
All these steps were carried out under aseptic conditions. The test was carried out in triplicates

Calculation: $\%$ inhibition $=$ sample inhibition zone $(\mathrm{cm}) /$ plate diameter x 100)

The results were statistically analyzed using the Student's "t" test (Sendecor and Cohran 1982).

\section{RESULTS AND DISCUSSION}

Phytochemical investigation of the defatted aqueous EtOH extract (DFAE) of Leucaena leucocephala leaves afforded 8 flavonoids (1-8). Compound (1) was isolated as yellow powder with $\mathrm{Rf}$ value of $0.73(15 \%$ HOAC), negative ESI-MS showed a molecular ion peak at $\mathrm{m} / \mathrm{z} 755.23\left[\mathrm{M}^{+}-\mathrm{H}\right]^{-}$with a molecular formula $\mathrm{C}_{36} \mathrm{H}_{36} \mathrm{O}_{18}$. The $\mathrm{UV}$ spectral data using various shift reagents indicated a flavonol skeleton with free hydroxyl groups at, C4, C-5 and C-7 while hydroxyl at C3 position is occupied (band I at 350nm) (Mabry et al. 1970; Markham 1982). Acid hydrolysis gave quercetin aglycone, $p$-coumaric acid in organic layer and glucose, rhamnose in aqueous phase. $p$-coumaric acid cis/trans give blue fluorescence in UV light (254nm) deepened after visualization with $5 \%$ methanolic potassium hydroxide.

The ${ }^{1} \mathrm{H}-\mathrm{NMR}$ spectrum in MeOD spectrum of compound 1 exhibited typical signals for querectin moiety. The douplet at $\delta 7.551$ and dd at $\delta 7.530 \mathrm{ppm}$, integrated for two protons, H-2', H6'. The doublet at $6.860(\mathrm{~J}=8.5 \mathrm{~Hz})$ was assigned for H-5'. Two proton doublets at 6.035 and 6.220 , each with $J=1.5 \mathrm{~Hz}$ due to meta-coupling were assigned for $\mathrm{H}-6$ and $\mathrm{H}-8$, respectively, and a trans $p$-coumaroyl moiety at $\delta 7.321\left(1 \mathrm{H}, \mathrm{d}, J=16 \mathrm{~Hz}, \mathrm{H}-7^{\prime \prime \prime}\right)$, $7.202\left(2 \mathrm{H}\right.$, brd, $\left.J=8.5 \mathrm{~Hz}, \mathrm{H}-2^{\prime \prime \prime}, 6^{\prime \prime \prime}\right)$, two doublet at $6.751(2 \mathrm{H}$, brd, $J=8.5 \mathrm{~Hz}, \mathrm{H}-3^{\prime \prime}, 5^{\prime \prime \prime)} 6.004$ (1H, dd, $\left.J=16,1.2 \mathrm{~Hz}, \mathrm{H}-8{ }^{\prime \prime}\right)$, the spectrum showed the two signals for anomeric protons of sugar at $\delta 5.687(1 \mathrm{H}, \mathrm{d}, J=7.4 \mathrm{~Hz}, \mathrm{H}-1 ")$ and $5.219(1 \mathrm{H}, \mathrm{d}, J=1.5$ Hz, H-1"').
The coupling constant of $J=7.4 \mathrm{~Hz}$ indicated a $\beta$-configuration for the glucose moiety and with $J=1.5 \mathrm{~Hz}$ indicating the $\alpha$ configuration of rhamnose moiety located at C-3 (Harborne, 1994). The H-6" proton signals of the glucose moiety was shifted downfield at $\delta: 4.45\left({ }^{1} \mathrm{H}, \mathrm{d}, J=11.5 \mathrm{~Hz} \mathrm{H}-6{ }^{\prime \prime} \mathrm{a}\right)$ and $4.20\left({ }^{1} \mathrm{H}\right.$, dd, $J=11.6,6.7 \mathrm{~Hz} \mathrm{H}^{\prime \prime}-\mathrm{b}$ ) in addition the $\mathrm{H}-2$ " proton signals of the glucose moiety were shifted downfield at $\delta: 4.85)$, this indicate substitution of C6"and C2" of glucose. ${ }^{13} \mathrm{C}$ - NMR spectrum of 1 revealed the presence of 12 carbon resonances in the aliphatic region which were assigned to glucose attached rhamnose moiety, among which the most downfield signals at $\delta 102.63, \delta 100.66$ ppm were assigned to the two anomeric carbons C-1" and C-1"' respectively. Furthermore, the downfield shift of C-6" (63.07) and C2" (77.50) of the glucose revealed their substitution by rhamnosyl moiety and trans p-coumaroyl moiety. HMBC (Heteronuclear multiple bond connectivity) correlation was between $\delta 5.687$ of (H1" glucose) and $\delta 134.51$ (C-3), 5.219 (H1'", rhamnose) and 64.25 (C-6, glucose) and correlation between $\delta$ 7.321 (H-7'"' of p- coumaric acid) and $\delta 165.68$ (carbonyl group of $p$-coumaric acid) and between $\delta 4.85$ (H-2", glucose) and $\delta 165.68$, these correlations revealed that glucose is substituting position 3 of the flavanol moiety and is substituted by rhamnose moieties at C-6 and trans $p$-coumaric acid at C-2". From the above data, compound 1 is identified as Quercetin-3-O-(2"-trans-p-coumaroyl)- $\alpha$ rhamnopyranosyl-(1"' $\rightarrow 6$ ")- $\beta$-glucopyranoside (Fig. 1). data was in agreement with the published data (Olea, et al., 1997). Compounds 2-8 were isolated for the first time from $L$. leucocephala leaves and were identified as quercetin-3-O- $\alpha-$ rhamnopyranosyl-(1"' $\rightarrow 2$ ") - $\beta$-glucopyranoside(2), Quercetin -7O- $\alpha$-rhamnopyranosyl-(1"' $\rightarrow 2$ ") - $\beta$-glucopyranoside (3),quercetin3 -O- $\alpha$-rhamnopyranoside(4), quercetin-3-O- $\beta$-glucopyranoside(5) isovitexin (6) vitexin (7) and quercetin(8) according to spectral data that were identical to those previously published (Agrawal 1989; Markham and Geiger 1994). Structure of compounds 1-8 are illusterated in Fig.2.

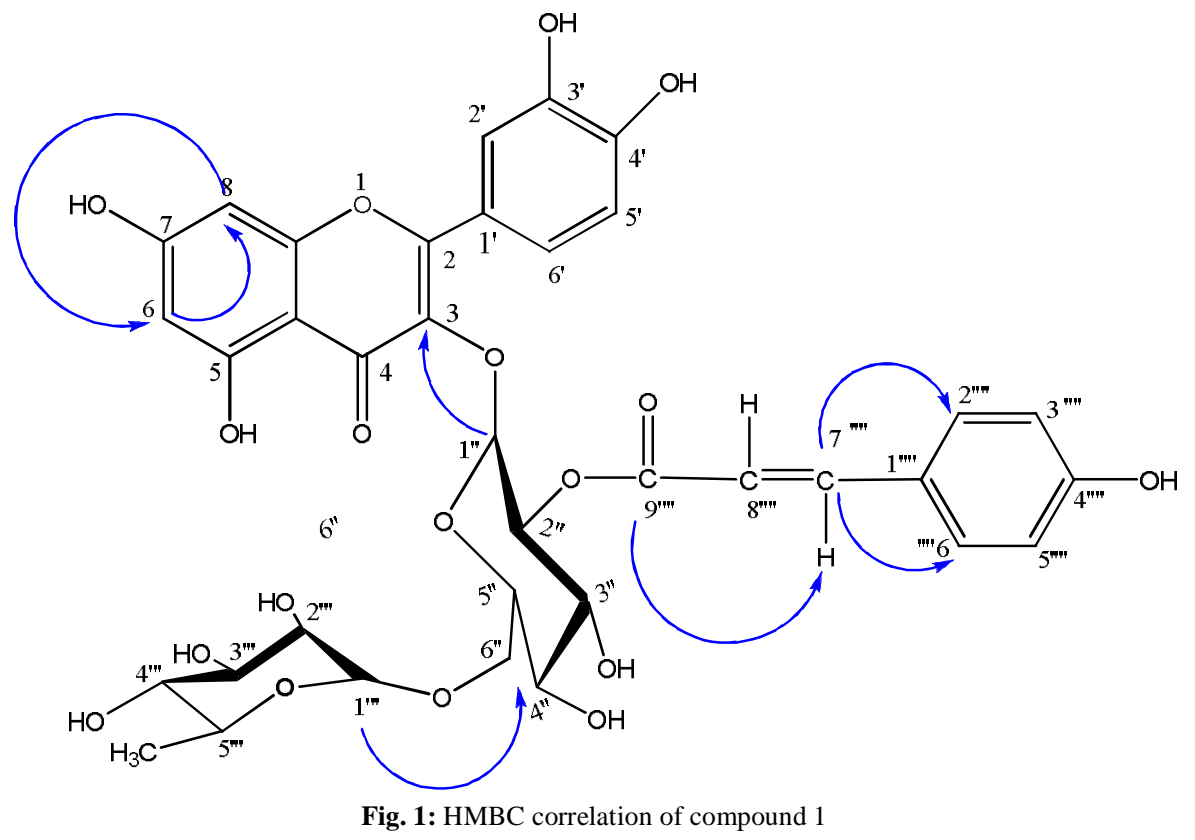



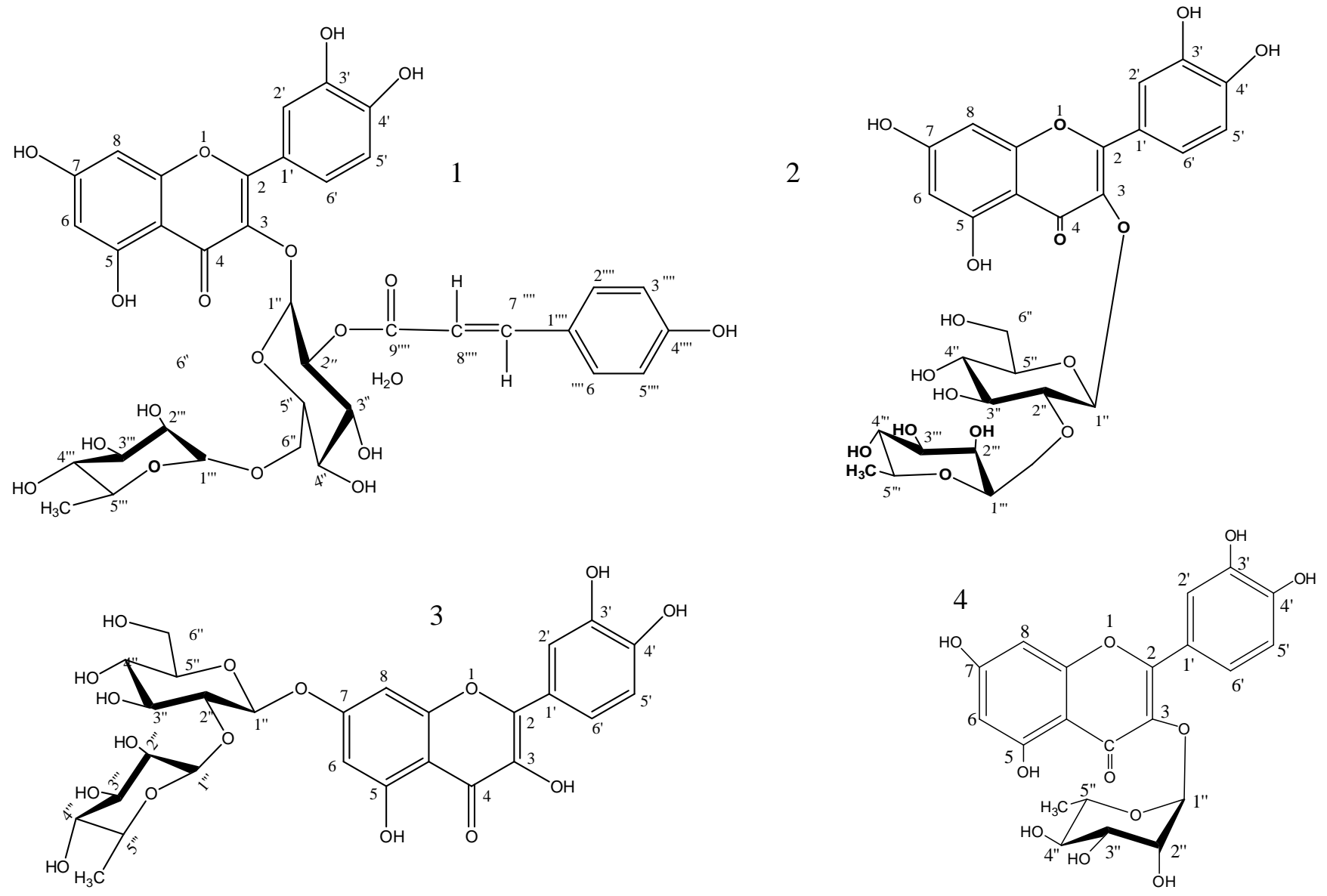<smiles></smiles><smiles></smiles><smiles>O=c1cc(-c2ccc(O)cc2)oc2cc(O)c([C@H](O)[C@H]3O[C@H](CO)[C@@H](O)[C@H]3O)c(O)c12</smiles>

Fig. 2: chemical structure of compounds 1-8. 


\section{Antioxidant activity}

The antioxidant capacity of the extract from plant is influenced by lots of factors, such as composition of the extract and test system and cannot be fully described with one single method. A reliable antioxidant protocol requires the measurement of more than one property because most natural antioxidants are multifunctional. Therefore, it is essential to perform more than one type of antioxidant capacity measurement to take into account the various mechanisms of antioxidant action (Wong et al., 2006).

Reducing power (RP) is the measurement of the reductive ability of antioxidant, and it is evaluated by the transformation of $\mathrm{Fe}$ (III) to $\mathrm{Fe}$ (II) in the presence of the sample extracts (Gülçin et al., 2003). The absorbance at $700 \mathrm{~nm}$ corresponds high RP of isolated compounds and total extract of $L$. leucocephala Table 1).The data show that all the samples exhibited potent with similar reducing power ability interestingly compound 3 was as near as $(0.651 \pm 0.017)$ to the reductive ability of BHT $(0.73 \pm 0.046)$.

Table 1: Antioxidant activity of Leucaena leucocephala leaves extract and isolated compounds.

\begin{tabular}{lll}
\hline Treatments & $\begin{array}{c}\text { Reducing Power } \\
(\text { Abs. at 700 } \mathbf{~ n m})\end{array}$ & $\begin{array}{c}\text { FRAP }(\boldsymbol{\mu} \text { mol Trolox/ 100 g } \\
\text { dry weight basis })\end{array}$ \\
\hline Total extract & $0.573 \pm 0.007$ & $2353 \pm 35.12$ \\
(Compound 1) & $0.572 \pm 0.008$ & $2787 \pm 72.11$ \\
(Compound 3) & $0.651 \pm 0.017$ & $3504 \pm 10.69$ \\
(Compound 4) & $0.536 \pm 0.009$ & $1395 \pm 17.8$ \\
BHT & $0.73 \pm 0.046$ & - \\
LSD $(0.05 \%)$ & 0.041 & 77.00 \\
\hline Data are means \pm standard deviation of triplicate experiments.
\end{tabular}

The FRAP test was used to measure the total antioxidant capacity method and based on the reduction of a ferric-tri pyridyltriazine complex to its ferrous colored form in the presence of antioxidants, and is regarded as accurate indicators of total antioxidant power, since total reducing power is defined as the sum of the reducing powers of the individual compounds contained in a particular sample (Tezcan et al., 2011). The ferric reducing ability of total extract of $L$. leucocephala and isolated compounds expressed as FRAP values ( $\mu$ mol Trolox/100 g dry weight) are shown in Table (1). Compound 3 had the highest FRAP value of $3504 \mu \mathrm{mol}$ Trolox/100 $\mathrm{g}$ dry weight followed by compound 1 (2787 $\mu$ mol Trolox/100 g dry weight) and total extract $(2353 \mu \mathrm{mol}$ Trolox/100 g dry weight), while compound 4 exhibited the lowest FRAP value it is about $1395 \mu$ mol Trolox/100 g dry weight Thus All compounds showed FRAP ability.

DPPH is a stable nitrogen centered free radical, the color of which changes from violet to yellow upon reduction by either the process of hydrogen capture or electron donation. Substances which are able to perform this reaction can be considered as antioxidants and therefore radical scavengers (Ebrahimzadeh et al., 2009b and Nabavi et al., 2008). From figure 3 it is evident that the radical scavenging activity of total extract and isolated compounds of L. leucocephala leaves extract ranged from $20.63 \%$ to $60.7 \%$ for compound 4 and compound 3 respectively, concerning on compound 1 it exhibited acceptable DPPH inhibition \% $(47.31 \%)$ at concentration of $50 \mu \mathrm{g} / \mathrm{ml}$.Our results are as near as with those obtained by Haggag et al., 2011).

Iron chelators reduce iron-related complications in human and thereby improve quality of life and overall survival in some diseases such as thalassemia major or Alzheimer's disease Grazul and Budzisz (2009). Bivalent transition metal ions play an important role as catalysts of oxidative processes (Halliwell, 1997). These processes can be delayed by iron chelation and deactivation. The transition metal iron, is capable of generating free radicals from peroxides by Fenton reactions and may be implicated in human cardiovascular diseases (Ebrahimzadeh et al., 2009a). Thus, minimizing $\mathrm{Fe} 2^{+}$concentration affords protection against oxidative damage. Results of iron chelating capacity were presented in figure (4). Compound 3 showed better activities with $35.56 \%$ followed by compound 1 with $24.72 \%$ inhibition percent, but the activity was very weak for total extract (16.64\%). Many researches focused on some natural products, especially flavonoids that possess direct influence on iron (III) ions level within tissues. (Grazul and Budzisz, 2009).

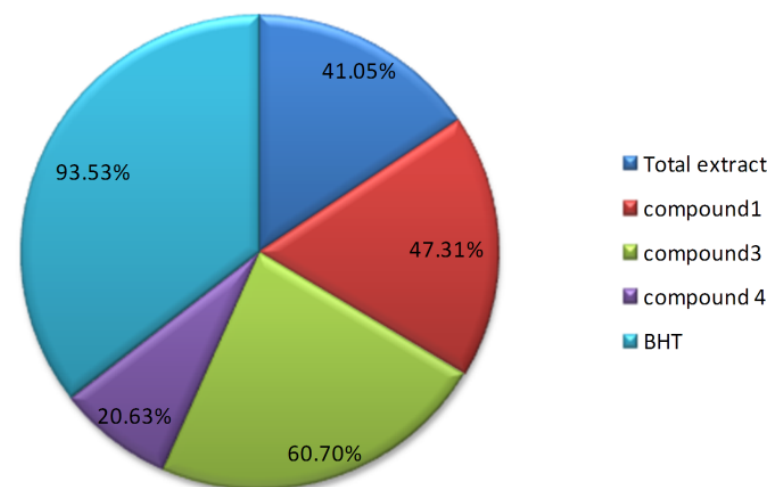

Fig. 3: Scavenging ability of Leucaena leucocephala leaves extract and isolated compounds on DPPH radical, (Data are means of triplicate experiments, $\operatorname{LSD} 0.05 \%=2.21$ ).

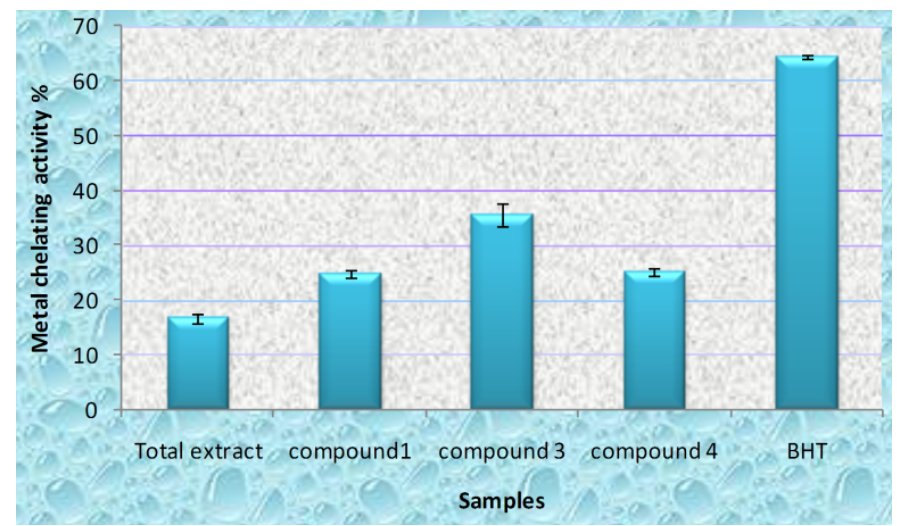

Fig. 4: Metal chelating activity of Leucaena leucocephala leaves extract and isolated compounds, (Data are means \pm standard deviation of triplicate experiments, LSD $0.05 \%=1.89)$.

Proton radical scavenging is an important attribute of antioxidants. ABTS a protonated radical has characteristic absorbance maxima at $734 \mathrm{~nm}$ which decreases with the scavenging of the proton radicals (Mathew and Abraham 2006). It 
was noted in figure 5 that Compound 3 at $50 \mu \mathrm{g} / \mathrm{ml}$ recorded $(65.19 \%)$ fast and effective scavengers of the ABTS radical and this activity was comparable to that of BHT at the same concentration inhibition percent was $88.68 \%$. On the other hand, Moderately levels of antioxidant activity were presented with compound 1, 4 and total extract, They found to be $48.59 \%$, $42.05 \%$ and $45.24 \%$ respectively.

A sample possessing ABTS free radical-scavenging activity indicated that it acts as a hydrogen donor and terminated the oxidation process by converting free radicals to more stable products, whereas a compound exhibiting a positive result in the FRAP assay was an electron donor and it terminated the oxidation chain reaction by reducing the oxidized intermediates into the stable form (Suganya et al., 2007). On the other hand Wang et al., (1998) found that some compounds which have ABTS+ scavenging activity did not show DPPH scavenging activity.

Antioxidant activity mean the ability of compounds to prevent damage from reactive oxygen species (ROS) or to prevent their generation (Ku“hnau ,1976). Reactive oxygen species and reactive nitrogen species (RNS) are major sources of oxidative stress in cells, damaging proteins, lipids, and DNA (Orrenius et $a l$. , 2007). Oxidative DNA damage is the major cause of cancer (Huang 2003, Hajiliadis 1997), aging and neurodegenerative diseases (Alzheimer's and Parkinson's) (Markesbery and Lovell 2006; Drew and Leeuwenburgh 2002), cardiovascular diseases (Vokurkova and Touyz 2007; Steinberg 1997), cell death and tissue damage resulting from heart attack and stroke (Ide et al. 2001; Uddin and Ahmad 1995). So prevention of oxidative stress caused by ROS and RNS has important effect for the prevention and treatment of disease.

Free radicals are reactive molecular species with unpaired electrons that oxidize other molecules to gain electrons and stabilize themselves. The reaction produces another free radical, initiating a chain reaction of free radical formation and stabilization (Machlin and Bendich 1987). Free radicals are normally generated in the body during biological process when an imbalance occur between generation and the defense mechanisms of the body oxidative damage will occur and will affect all the cell targets (DNA, lipids, proteins). Free radical damage can cause unsaturated bonds in membrane lipids to lose fluidity and proteins to denature (Machlin and Bendich 1987).

Flavonoids are importance class of phenolic compounds found to have antioxidant and free radical scavenging capacities that are much stronger than those of vitamins $\mathrm{C}$ and $\mathrm{E}$ (Prior and Cao (2000), Shahidi and Wanasundara 1992). The radicalscavenging activity of flavonoids depends on the molecular structure and the substitution pattern of hydroxyl groups (Bors, et al., 1990; Rice-Evans, et al., 1996).

The structural requirement for effective radical scavenging by flavonoids is the presence of 3', 4'-dihydroxy in the $\mathrm{B}$ ring with electron donating properties and being a radical target, the presence of an O-dihydroxy structure in the B-ring confers a higher degree of stability on the flavonoid phenoxyl radicals by participating in electron delocalization and is an important feature for the antiradical potential (Bors, et al., 1990). Both 3-OH and 5$\mathrm{OH}$ groups in combination with the 4-carbonyl function and $\mathrm{C} 2$ C3 double bond increases the radical scavenging activity (Van Acke, 1996). The C2-C3 double bond conjugated with the 4-keto group, which is responsible for electron delocalization from the $\mathrm{B}$ ring; improve radical-scavenging capacity (Bors, et al., 1990; Cao, 1997).

Williamson et al., (1996) reported that Presence of free 3`, 4-dihydroxy group in the B ring as in quercetin increases the antioxidant activity as compared with the free mono-hydroxy as in kaempferol, substitution of one of the dihydroxy group in the B ring by methoxy group or occupation of $3 \mathrm{OH}$ group by a bulky sugar moieties decrease antioxidant activity Mohammed et al., (2014).

The high potential of flavonoid compounds $(\mathrm{FlOH})$ to scavenge free radicals (ROS) may be explained by their ability to donate a hydrogen atom from their hydroxyl group and thereby scavenge the free radicals. This reaction gives the flavonoid phenoxyl radicals $\left(\mathrm{FlO}^{*}\right)$ and a stable molecule $(\mathrm{RH})$. FlO* undergoes a resonance structure by redistributing the unpaired electron on the aromatic core. So flavonoid phenoxyl radicals exhibit a much lower reactivity compared to $\mathrm{R}^{*}$. FlO* would react further to form unreactive compounds, by radical-radical termination (Dragan, et al., 2003).

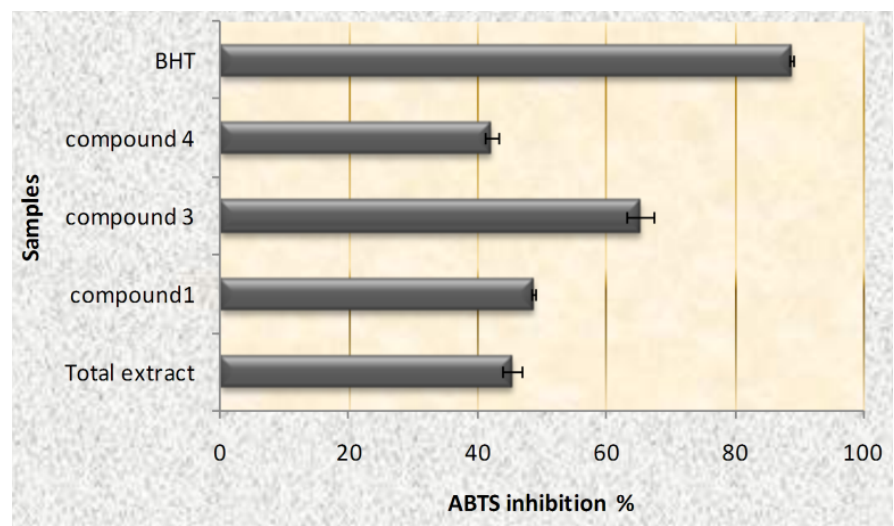

Fig. 5: Scavenging ability of Leucaena leucocephala leaves extract and isolated compounds on ABTS radicals, (Data are means \pm standard deviation of triplicate experiments, LSD $0.05 \%=5.31$ ).

In our study compound 3 which is a 7-O-substituted flavanol have significant strong reducing power than compound 1 and 4 this may be explained due to presence of all SAR requirement for active free radical scavenging activity. Compound 1 and 4 are 3 substituted flavonols glycoside so $\mathrm{OH}$ group in position 3 is occupied by a mono sugar in 4 and acylated disugar structure of compound 1, the latter showed higher activity than 4 this is may be due to the attached antioxidant activity of $p$ coumaric acid (Kiliç and Yeşiloğlu, 2013) it seems, this substitution make the structure of the compound to be more active against reaction with free radical than compound 3 . The extract and compounds $1,2,3$ and 4 were screened for their antimicrobial effect against gram +ve, -ve bacteria, fungi and yeast, using the diffusion assay method(Hammond and Lambert 1978). 
Table 2:Anti-microbial activity of the DAEE and different compounds of Leucaena leucocephala leaves .

\begin{tabular}{|c|c|c|c|c|c|c|}
\hline Microorganisms & \multicolumn{2}{|c|}{ Diameter of inhibition zone in $\mathrm{mm}$} & \multicolumn{2}{|l|}{ (\% Inhibition) } & Extract & Standard \\
\hline Staphylococcus aureus & $\begin{array}{l}13 \pm 0.82 \\
(42.86 \%)\end{array}$ & $\begin{array}{l}16 \pm 0.82 \\
(52.75 \%)\end{array}$ & $\begin{array}{l}17.33 \pm 0.22 \\
(57.13 \%)\end{array}$ & $\begin{array}{l}15.33 \pm 0.28 \\
(50.54 \%)\end{array}$ & $\begin{array}{l}10.33 \pm 0.40 \\
(34.05 \%)\end{array}$ & $30.33 \pm 0.34$ \\
\hline Escherichia coli (G-) & $\begin{array}{l}12.66 \pm 0.42 \\
(88.34 \%)\end{array}$ & $\begin{array}{l}12 \pm 1.41 \\
(83.74 \%)\end{array}$ & $\begin{array}{l}10 \pm 0.81 \\
(69.78 \%)\end{array}$ & $\begin{array}{l}12.33 \pm 1.25 \\
(86.04 \%)\end{array}$ & $\begin{array}{l}10.33 \pm 0.38 \\
(72.08 \%)\end{array}$ & $14.33 \pm 0.40$ \\
\hline Pseudomonas aeruginosa (G-) & $\begin{array}{l}13 \pm 0.82 \\
(66.12 \%)\end{array}$ & - & - & - & $\begin{array}{l}15.33 \pm 0.47 \\
(77.97 \%)\end{array}$ & $19.66 \pm 0.42$ \\
\hline Candida albicans & $\begin{array}{l}18.66 \pm .0 .91 \\
(46.26 \%)\end{array}$ & (20.0 & (5) & 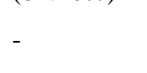 & $\begin{array}{l}14.66 \pm 1.42 \\
(36.35 \%)\end{array}$ & $40.33 \pm 0.33$ \\
\hline Asperagillus niger & - & $\begin{array}{l}20.33 \pm 1.79 \\
(58.08 \%) \\
958.08)\end{array}$ & - & $\begin{array}{l}20.33 \pm 0.78 \\
(58.08)\end{array}$ & - & $35 \pm 0.20$ \\
\hline Mucar miehei & - & $\begin{array}{l}18 \pm 0.82 \\
(72 \%)\end{array}$ & - & $\begin{array}{l}18.66 \pm 0.94 \\
(74.64 \%)\end{array}$ & $\begin{array}{l}19.33 \pm 0.43 \\
(77.3 \%)\end{array}$ & $25 \pm 0.10$ \\
\hline
\end{tabular}

Standard : Ampicillin: standard antibacterial.

Data are means \pm standard deviation of triplicate experiments.

The extract showed significant antimicrobial activity against gm -ve E. coli (72.08 \%) Pseudomonas (77.97 \%) and Salmonella typhimurium (63.64 \%), moderate activity against gm $+v e$ and candida weak activity as antifungal towards Mucar and ve activity towards other tested fungi. All tested compounds 1,2, 3 and 5 exhibited significant inhibition against Salmonella typhimurium and E coli $(97.74,95.49,81.85,84.10 \%)$ and (88.34, $83.74,69.78,86.04 \%)$ respectively. Compound 1 was the only effective compound against Pseudomonas and candida. Compound 2 and 4 revealed promising as antifungal against Aspergillus niger and Mucar miehei (58.08 \%, $58.08 \%$ and $(72 \%$, $74.64 \%$ ) respectively (Table 2). Antimicrobial activities observed in this study might be due to the presence of flavonoid compounds. It was reported that medicinal plants containing phenolic and flavonoid compounds possess antimicrobial activity (Ayaz et al., 2008; Rahman and Moon, 2007).

\section{CONCLUSION}

An acylated flavonol glycoside along with seven flavonoids were isolated for the first time from the dried leaves Leucaena leucocephala leaves their structures were based on quercetin and apigenin nucleus. The encouraging results with the various in vitro antioxidant tests proved that the plant has a reducing agent, metal chelator, hydrogen donating ability and effective as scavengers of hydrogen peroxide, and free radicals. DAEE and isolated flavonoidal compounds have significant activity against G-ve bacteria especially Escherichia coli and Salmonella typhimurium the plant can be used as antigram -ve bateria.

\section{ACKNOWLEDGEMENT}

Special appreciation is extended to the National Research Centre-Dokki- Giza Egypt for offering the facilities for this study.
Clotrimazole: standard antifungal.

\section{REFERENCES}

Agrawal, P.K. 1989. Carbone-13 NMR of flavonoids. Elsevier Science Publishing Co. Inc New york.

Ayaz F., HayIrlIoglu Ayaz, S., Alpay Karaoglu S., Gruz J., Valentová K., Ulrichová J., Strnad M. Phenolic acid contents of kale (Brassica oleraceae L. var. acephala DC.) extracts and their antioxidant and antibacterial activities. Food Chem. 2008; 107: 19-25.

Benzie, I.F.F., Strain, J.J. Ferric reducing, antioxidant power assay: Direct measure of total antioxidant activity of biological fluids and modified version for simultaneous measurement of total antioxidant power and ascorbic acid concentration. Methods Enzym. 1999; 299: 15-27

Bors, W., Heller, W., Michel, C., Saran, M., Flavonoids as antioxidants: determination of radical-scavenging efficiencies. Methods Enzymol. 1990;186: 343-355.

Brand-Williams, W., Cuvelier, M.E., Berset, C. Use of a free radical method to evaluate antioxidant activity. Lebensmittel Wissenschaften und Technologi. 1995; 28: 25-30.

Cao, G., Sofic, E., Prior, R.L. Antioxidant and prooxidant behavior of flavonoids: structure-activity relationships. Free Radical Biol. Med. 1997; 22, 749-760.

Chung-Yi Chen, Yau-Der Wang. Steroids from the Whole Plants of Leucaena leucocephala. American Journal of Analytical Chemistry, 2010; 1: 31-33.

Dillon J.R., Nasim A., Nestmann E.R. 1985. Recombinant DNA Methodology. New York: John Wiley and Sons, , Inc.

Dinis, T.C.P., Madeira, V.M.C., Almeida, L.M. Action of phenolic derivatives (acetaminophen, salicylate and 5-aminosalicylate) as inhibitors of membrane lipid peroxidation as peroxyl radical scavenging effects. Chemical Pharmacology Bulletin, 1994; 36: 2090-2097.

Dragan A., Dusanka D.A., Drago B., Nenad T. StructureRadical Scavenging Activity Relationships of Flavonoids. CROATICA CHEMICA ACTA, 2003; 76 (1): 55-61.

Drew, B., Leeuwenburgh, C. Aging and the role of reactive nitrogen species. Annals of the New York Academy of Sciences, 2002; 959: 66-81.

Duthie, G.G. Lipid peroxidation. European Journal of Clinical Nutrition, 1993; 47(11): 759-764.

Ebrahimzadeh, M.A., Nabavi, S.F. Nabavi, S.M. Essential oil composition and antioxidant activity of Pterocarya fraxinifolia. Pak J Biol Sci. 2009a; 12: 957-963. 
Ebrahimzadeh, M.A., Nabavi, S.M., Nabavi, S.F., Eslamim, B. Free radical scavenging ability of methanolic extract of Hyoscyamus squarrosus leaves. Pharmacologyonline. 2009b ; 2: 796-802.

Erickson, A.J., Ramsewak, R.S., Smucker, A.J. Nair, M.G. Nitrification Inhibitors from the Roots of Leucaena leucocephala. Journal of Agricultural and Food Chemistry, 2000; 48(12): 6174- 6177.

Gamal-Eldeen, A.M., Amer, H., Helmy, W.A., Talaat, R.M. Ragab, H. Chemically-Modified Polysaccharide Extract Derived from Leucaena leucocephala. Alters Raw 264.7 Murine Macrophage Functions. International Immunopharmacology, 2007; 7(6): 871-878.

Grazul, M., Budzisz, E. Biological activity of metal ions complexes of chromones, coumarins and flavones. Coordin Chem Rev. 2009; 253: 2588-2598

Gülçin, I., Oktay, M., Kıreçci, E., Küfrevio, lu I. Screening of antioxidant and antimicrobial activities of anise (Pimpella anisum L.) seed extracts. Food. Chem. 2003; 83: 371-382.

Haggag, E. G., Kamal, A. M., Abdelhady, M. I. S., El- Sayed, M. M., El-Wakil, Eman A., Abd-El-hamed, S. S. Antioxidant and cytotoxic activity of polyphenolic compounds isolated from the leaves of Leucenia leucocephala. Pharmaceutical Biology, 2011; 49(11): 1103-1113

Halliwell, B. Antioxidants: the basics- what they are and how to evaluate them. Adv Pharmacol. 1997; 38: 3-20.

Hammond S.M., Lambert P.A. 1978. Antibiotic and Antimicrobial Activity Action. London: Edward Arnold.

Huang, X. Iron overload and its association with cancer risk in humans: Evidence for iron as a carcinogenic metal. Mutation Research 2003; 533: 153-171.

Ide, T., Tsutsui, H., Hayashidani, S., Kang, D., Suematsu, N., Nakamura, K.I., et al. Mitochondrial DNA damage and dysfunction associated with oxidative stress in failing hearts after myocardial infarction. Circulation Research, 2001; 88: 529-535.

Kiliç, I., Yeşiloğlu, Y. Spectroscopic studies on the antioxidant activity of p-coumaric acid. Spectrochim Acta A Mol Biomol Spectrosc. 2013; 115:719-24

Kinsella, J.E., Frankel, E., German, and Kanner, J. Possible mechanisms for the protective role of antioxidants in wine and plant foods. Food Technology, 1993; 47: 85-89.

Ku'hnau, J. The flavonoids: A class of semi-essential food components: Their role in human nutrition. World Review of Nutrition and Dietetics. 1976; 24: 117-191.

Lalitha K., Vargheese, C.M., Balasubramanian, N. Spectrophotometric determination of mimosine and 3-Hydroxy-4- $(1 \mathrm{H})-$ pyridone - The toxic principles of L. leucocephala. Analyt. Biochem. 1993; 213: 57-62.

Lowry, J.B., Cook, N., Wilson, R.D. Flavonol glycoside distribution in cultivars\& hybrids of 1 leuocephala. J. Sci.Food Agric., 1984; 35: 401.

Mabry, T.J., Markham, K.R., Thomas, M.B. 1970. The Systematic Identification of Flavonoids. Berlin: Springer.

Machlin, L.J. Bendich, A. Free radical tissue damage: protective role of antioxidant nutrients. The FASEB Journal, 1987; 1: 441-445.

Markham, K.R. 1982. Techniques of Flavonoid Identification. Academic Press, London.

Markham, K.R., Geiger, H., 1994. 1H-NMR of flavonoids and their glycosides in DMSO-d6. In: Harborne JB, editor. The Flavonoids: Advances in Research since 1986. London: Chapman and Hall.

Markesbery, W. R., Lovell, M.A. DNA oxidation in Alzheimer's disease. Antioxidants and Redox Signaling, 2006;8: 2039-45.

Marshall R.T. 1993. Standard methods for the microbiological examination of dairy products. RT Marshall editor. 16 ed. Wahington D.C. : American Public Health.

Mathew, S., Abraham, T.E. In vitro antioxidant activity and scavenging effects of Cinnamomum verum leaf extract assayed by different methodologies. Food Chemistry and Toxicology. 2006; 44: 198206.

Michael, H.N., Salib, J.Y. Flavonoids from leucaeua gluca pods Bull. Fac. Pharm. Cairo. Univ., 2007; 45(1): 155-160.

Mohammed, R.S., Abou Zeid, A.H., El-Kashoury, E.A., Sleem, A.A. Waly, D.A. A new flavonol glycoside and biological activities of
Adenanthera pavonina L. leaves. Natural Product Research, 2014; 28 (5): 282-289.

Nabavi, S.M., Ebrahimzadeh, M.A., Nabavi, S.F., Jafari, M. Free radical scavenging activity and antioxidant capacity of Eryngium caucasicum Trautv and Froriepia subpinnata. Pharmacologyonline. 2008; 3: $19-25$

Nair, A.G.R. Subramanian, S.S. Flavonoids of the flower of Dombeya Calantha \& leucaeua gluca Cur.Sci, 1962; 31: 155-504.

Nokata, M., Munchisa, A., Machiko, N., Hong-Yen Hsu., YuhPan Chen. Studies on the constituents of Formosan Leguminosae Shoyokugaka Zasshi, 1977; 31(2):172-4.

Olea R. S. G., Roque N.F., Bolzani V. S. Acylated flavonol glycosides and terpenoids from the leaves of Alibertia sessilis. J. Braz Chem. Soc. 1997; 8(3): 257-259.

Orrenius, S., Gogvadze, V. Zhivotovsky, B. Mitochondrial oxidative stress: Implications for cell death. Annual Review of Pharmacology and Toxicology, 2007;47: 143-183.

Oyaizu, M. Studies on the product of browning reaction prepared from glucosamine. Jpn J. Nutrition. 1986; 44: 307- 315.

Prior, R.L., Cao, G.H. Analysis of botanicals and dietary supplements for antioxidant capacity: Areview. J AOAC INT. 2000; 83(4), 950-956.

Rahman, M., Moon, S. Antimicrobial phenolic derivatives from Dendranthema zawadskiivar. latilobum kitamura (Asteraceae). Arch Pharm. Res., 2007; 30: 1374-1379.

Ramana, D.B.V., Singh, S., Solanki, K.R., Negi, A.S. Nutrative evaluation of some nitrogen and non-nitrogen fixing multipurpose tree species. Animal Feed Sci. Technol. 2000; 88: 103-111.

Ranganthan, R.M., Nagarajan, S. Flavonoids of the flower of leucaeua gluca., Cur Sci., 1980; 49: 546.

Re R, Pellegrini, N., Proteggente, A., Pannala, A., Yang, M., Rice-Evans, C. Antioxidant activity applying an improved ABTS radical cation decolorization assay. Free Radical Biology and Medicine, 1999; 26: 1231-1237.

Rice-Evans, C.A., Miller, N.J., Paganga, G. Structure antioxidant activity relationships of flavonoids and phenolic acids. Free Radical Biology and Medicine, 1996; 20: 933-956.

Salem, A.Z.M., Salem, M.Z.M., Gonzalez-Ronquillo, M., Camacho, L.M., Cipriano, M. J. Trop. Agri., 2011; 49 (1-2): 95-98.

Shahidi, F., Janitha, P.K. Wanasundara. Phenolic antioxidants Critical Reviews in Food Science, 1992; 32: 67-103.

Sendecor W.G, Cohran G.W. 1982. Statistical methods. 10th ed. Iowa State: Iowa State University press.

Steinberg, D. Low density lipoprotein oxidation and its pathobiological significance. J.Bio. Chem., 1997; 272: 20963-20966.

Subba Rao N.S. Soil Microorganisms and Plant Growth 1977. New Delhi: Oxford and IBH Publishing Co.

Suganya, T., Siriporn, O., Sombat, C. Study on antioxidant activity of certain plants in Thailand: Mechanism of antioxidant action of guava leaf extract. Food Chem. 2007; 103: 381-388.

Terao, J., Piskula, M.K. 1997. Flavonoids as inhibitors of lipid peroxidation in membranes. In C. A. Rice-Evans \& L. Packer (Eds.) Flavonoids in health and disease (pp. 277-295). New York: Marcel Dekker.

Tezcan, F., Kolayl1, S., Sahin, H., Ulusoy, E., Erim, B.F. Evaluation of organic acid, saccharide composition and antioxidant properties of some authentic Turkish honeys. J. Food Nutr. Res. 2011; 50: $33-40$.

Uddin, S., Ahmad, S. Dietary antioxidants protection against oxidative stress. Biochemical Education, 1995; 23: 2-7.

Valentao, P., Fernandes, E., Carvalho, F., Andrade, P.B., Seabra, R.M. Bastos, M. Antioxidative properties of cardoon (Cynara cardunculus L.) Infusion against superoxide radical, hydroxyl radical and hypochlorous acid. Journal of Agricultural and Food Chemistry, 2002; 50: 4989-4993.

Van Acker, S.A.B.E., de Groot, M. J., van den Berg, D. J., Tromp, M.N.J.L., den Kelder, G., van der Vijgh, W.J.F., Bast, A. A quantum chemical explanation of the antioxidant activity of flavonoids. Chem. Res. Toxicol. 1996; 9: 1305-1312. 
Vokurkova, M., Xu, S., Touyz, R.M. Reactive oxygen species, cell growth, cell cycle progression and vascular remodeling in hypertension. Future Cardiology, 2007; 3: 53-63.

Wang, M., Li, J., Rangarajan, M,. Shao, Y., La Voie, E.J., Huang, T.. Ho, C. Antioxidative phenolic compounds from Sage (Salvia officinalis). Journal of Agriculture and Food Chemistry. 1998; 46: 48694873.

Williamson, G., Plumb, G.W., Uda, Y., Price, K.R., Rhodes, M.J.C. Dietary quercetin glycosides: antioxidant activity and induction of the anticarcinogenic phase II marker enzyme quinone reductase in Hepalclc7 cells. Carcinogenesis. 1996; 17(11): 2385-2387.

Wong, S.P., Leong, L.P., Koh, J.H.W. Antioxidant activities of aqueous extracts of selected plants. Food Chem. 2006; 99, 775-783.

Yeung. P. K. K., Wong, F.T.W., Wong, J. T.Y. Mimosine the allelochemical from the leguminous tree $L$. leucocephala, selectively enhances cell Proliferation in dinoflagellates. App. Environ. Microbiol. 2004; 68: 5160- 5163.

\section{How to cite this article:}

Reda S. Mohammed, Sahar S. El Souda, Hanan A.A. Taie, Maysa E. Moharam and Kamel H. Shaker. Antioxidant, antimicrobial activities of flavonoids glycoside from Leucaena leucocephala leaves. J App Pharm Sci, 2015; 5 (06): 138-147. 